\title{
Framework for Exploring Fit and Flexibility in Strategic Human Resource Management in Jordanian Telecommunication Companies
}

\author{
Hisham A. Kareem Shaheen and Ahmad Ali Almohtaseb
}

\begin{abstract}
The Fit and flexibility is now very imperative for an effective strategic human resource management. Theoretical and empirical studies however could not agree on a single framework to accommodate both of its concepts (orthogonal and complimentary) to solve human resource management issues globally. The lack of a framework is a concern because there are still pertinent issues relating to human resource management specifically in Jordan. The purpose of this study was to carry out a conceptual framework to explore the fit and flexibility concept in strategic human resource management in Jordanian Telecommunication companies. This study suggests that emphasis should be placed on strategic flexibility in a dynamic sector like the Jordanian telecommunication sector to improve their productivity, performance and achieve a competitive advantage. Also, Jordanian Telecommunications companies' strategic flexibility will be achieved only if they rely on developing innovative and sustainable HR practices to stay competitive in their rapidly changing and dynamic business environment.
\end{abstract}

Index Terms - strategic, human resource management, fit, flexibility, Jordan.

\section{INTRODUCTION}

There is no clear understanding and agreement on the definition, value and the link between the fit and flexibility concept in the strategic human resource management (HRM) context (Baird \&Meshoulam, 1988; Torrington et al., 2005;Wei, 2006; Wright, 1998; Wright \& McMahan, 2011; Wright \& Snell, 1998). There are many theories at the individual, group, and organizational levels when analyzing the concept of fit (Martin-Alcazar et al., 2005; Paauwe, 2004; Venkatraman, 1989). Nadler and Tushman (1980, p. 40) define fit as "the degree to which the needs, demands, goals, objectives and/or structure of one component are consistent with the needs, demands, goals, objectives, and/or structure of another component ". What is always apparent and very intrinsic in treating fit is the idea that organizations are more effective and efficient when they attain fit than when fit is not attained (Baird \& Meshoulam, 1988;Delery\&Roumpi, 2017; Lengnick-Hall \& LengnickHall, 1988; Milliman et al., 1991; Montemayor, 1996; Nadler \& Tushman, 1980; Venkatraman, 1989; Wei, 2006).

By contrast, Sanchez (1995, p. 138) defines flexibility as

Published on February 22, 2020.

Hisham A. Kareem Shaheen, Amman Training College, UNRWA, Business School, Amman, Jordan.

(e-mail: Hisham_shaheen2003@yahoo.com)

Ahmad Ali Almohtaseb, Al Hussein University, Business Department, Ma'an, Jordan.

(e-mail: Muhtaseb_ma@yahoo.com) "a firm's abilities to respond to various demands from the dynamic competitive environments". Also, flexibility gives organizations the capability to amend their present practices in response to non-transient fluctuations in the environment. Flexibility necessitates organizations to perceive changes in their environment and to hold on to enough of a pool of innovative actions so that there can be accommodation for the changes (Wright, 1998; Wright \& McMahan, 2011; Wright \& Snell, 1998). Teece et al. (1997, p.520) stresses the necessity for organizations in dynamic environment to "reconfigure the firm's asset structure, and to accomplish the necessary internal and external transformations". Highflexibility organizations have the ability to quickly accomplish reconfiguration and transformation ahead of competition".

There are two views regarding the fit and flexibility relationship in strategic HRM studies (Milliman et al., 1991). One view is the "orthogonal" perspective that argues that fit and flexibility are opposite of each other, indicating that the two cannot occur concurrently (Lengnick-Hall \& Lengnick-Hall, 1988). The other view is the "complementary" perspective that argues that fit and flexibility are independent of one another, indicating that both concepts are crucial for effective organizations because the challenge of strategic management is to manage the change (needing flexibility) through continuously acclimatizing to attain a fit between the organization and its external environment (Milliman et al., 1991).

The variations between these two views are as result of the variations relating to the time frame as well as from variations relating to the objectives of the study (Wei, 2006). Based on the time frame, studies promoting the orthogonal perspective focused on organizations at a time and contend that both the fit and flexibility could not occur concurrently. However, supporters of the complementary perspective view fit as a taking a longer time horizon and exploring the process of adaptation. Relating to the objectives of research, supporters of the orthogonal perspective often focused on description which means what organizations actually do, while supporters of the complementary perspective often focus on prescription, which means what firms must to do. (Wright \& McMahan, 2011; Wright \& Snell, 1998; Wei, 2006).

\section{A. HRM in Jordan}

There are only a few studies about HRM in Jordan(e.g., Abdalla \& Al-Homoud, 1995; Abdelhafiz et al., 2015; AbuAlRub \& Nasrallah, 2017; Alhamwan et al., 2015; Alawneh et al., 2015; Altarawneh, 2009; Al-Athari \& Zairi, 2002; Higazee et al., 2016), and these studies are not built 
on real empirical HRM issues. Also, there is lack of systematic analysis that may provide a comprehensive image of the HRM dynamics in Jordan, which has made it difficult to discuss on effective direction for present or future HRM strategies and practices in Jordan (Melham, 2004; Afana, 2004; Abu-Doleh, 2000).However, some studies (e.g., Abu-Doleh, 2000; Al-Shaikh, 1997; AlRasheed, 1994) have argued that there is a necessity for developing economies like Jordan to strengthen their organizational and human resource management for future development. As identified by Abu-Doleh (2000),Afana(2004); Melham (2004) and Weir (1997); improvement in the practice of HRM among Jordanian organizations may only occur if there is clear understanding of the nature of the current applications by the organizations.

Though, the HRM practices in Jordan are influenced by the national cultural values which are reflected in the government's policies and bureaucratic processes. Furthermore, HR managers rarely participated in designing and establishing HR practices, and strategic decision making in public and private sector settings in Jordan (Aladwan et al., 2014; Al-Athari \& Zairi, 2002; Budhwar \& Mellahi, 2006). Abu-Doleh (2000) stressed that there is little to be expected in developing and efficiently enhancing strategic HRM and professional practices in Jordan without a clear understanding and stressing the nature of the roles of the HR managers in Jordanian organizations. In lieu of the level of HRM practice in Jordan, this study proposed that fit and flexibility are complementary in the strategic HRM of Jordanian companies and specifically companies in the telecommunication sector.

\section{LITERATURE REVIEW}

\section{A. Fit and Strategic HRM}

When examining "fit" in strategic HRM, there is a need to look at the argument on what should be "fitted". In this regard, past studies on strategic HRM have stressed that strategies should fit under three broad conceptual variables which are: HRM practices, employee skills, and employee behaviour. They are expounded upon as follows:

\section{Strategy-HRM Practices Fit :}

According to Schuler and Jackson (1987), a set of HRM practices are at the disposal of organizations; as employees play different roles of behaviours to different organizational strategies, and, therefore, an organization will select HRM practices based on its capability to elicit the required behaviours in implementing the chosen strategy. In the same vein, the study of Miles and Snow (1984) discussed the variations in HRM practices that need to be detected between prospector, defender, and types of analyzing strategies. Also, Wright and Snell (1991) stressed that both the types of organizational strategies as well as the directional strategies (e.g., retrenchment and growth) would impact the selected HRM practices. Furthermore, those that carry out empirical studies have examined the strategyHRM practices fit, specifically focusing on fit between HRM practices and business strategies (e.g., Delery \& Doty, 1996; Jackson et al., 1989; Youndt et al., 1996).

\section{Strategy-Employee Skills Fit :}

Fit between firms' strategy and employee skills have also been advocated by previous research. For instance, on the supposition that "different strategies require different types of people ... for effective performance" (Olian \& Rynes, 1984, p.171) studies (e.g., Olian \& Rynes, 1984; Kerr, 1982; Hambrick \& Mason, 1984; Gupta, 1984; Gerstein \& Reisman, 1983) have proposed the fit between general managers and chief executive officers.

Furthermore, many of the empirical studies carried out on fit have focused on the strategy-skill relationship. Past studies such as Wiersma and Bantel (1992), Michel and Hambrick (1992), Hitt and Tyler (1992), Bantel and Jackson (1989), and Gupta and Govindarajan (1984) have examined the relationship between several strategic types and managerial characteristics. Also, Wright et al. (1995) and Lengnick-Hall and Lengnick-Hall (1988) have examined this relationship on employees.

\section{Strategy-Employee Behaviour Fit :}

A fit between a firm's strategy and the types of behaviours displayed by employees have been called for by some studies in strategic HRM, particularly Schuler and Jackson(1987). The basic cause of the "behavioural perspective" is that different types of strategies required different role behaviours.

\section{B. Flexibility and Strategic HRM}

According to Sanchez (1995), flexibility is of two types, namely: resource flexibility and coordination flexibility. While resource flexibility is regarded as the degree to which a resource could be useful to a larger variety of alternate uses, the difficulty and cost of substituting the use of a resource from one alternate use to the another, and the needed time to substitute from one use to the another. On the other hand, coordination flexibility entails the degree to which an organization could resynthesize its strategies, reconfigure its resources, as well as redeploy its resources. However, these two types of flexibility are mainly appropriate for examining flexibility in strategic HRM.

Meanwhile, as there are quite precise discussions regarding fit in strategic HRM to determine the variables constituting fit, it is quite different in the case of flexibility. According to Milliman et al.(1991, p.325) that focused on HRM practices, flexibility is defined in HRM as "the capacity of HRM to facilitate the organization's ability to adapt effectively and in a timely manner to changing or diverse demands from either its environment or from within the firm itself". Snow and Snell (1993) lay emphasis on creating flexibility by hiring persons based on their ability to create value, while MacDuffie (1995) stressed that flexibility is from wide-ranging set of employee skills. The argument of these authors on flexibility is derived from seeing flexibility as a product of employees' skills.

\section{Flexibility and HRM Practices:}

The flexibility of HRM practices means the differences 
across business units and locations, the degree to which the basic practices are applied across different sites or jobs, or the rapidity in which practices could be changed (Carvalho \& Cabral-Cardoso, 2008; Chang et al., 2013; Kaiser et al., 2015; Knox \& Walsh, 2005; Stankevičiūtė \& Savanevičienė, 2018; Zhang et al., 2015).Therefore, HRM practices can also be described in the form of resource flexibility and coordination flexibility.

HRM practices and resource flexibility-the resource flexibility of HRM practices means the level at which they can be modified and used across diverse situations (Ketkar\& Sett, 2010; Way et al., 2015). Two features of flexibility are imperative. The first is the general use of HRM practices across situations and jobs in terms of the degree to which the practices must be completely redeveloped or redesigned so as to use for another situation (Ketkar \& Sett, 2010; Way et al., 2015; Tracey, 2012). HRM practices are different based on how they can easily be applied to different individuals and/or different jobs within a job (Ketkar \& Sett, 2010; Way et al., 2015; Sekhar et al., 2016; Tracey, 2012).

The second is based on the degree to which resource flexibility of HRM practices are firmly used across various sites and situations. There is need to know each of the links within the model perfectly in order to accomplish fit between strategy and HRM practices. This means that in matching HRM practices to a selected strategy, there is need for the HRM strategist to have full information of the behaviours and skills needed to achieve that strategy, and the precise HRM practices that would develop the skills and prompt those behaviours (Ketkar \& Sett, 2010; Michel \& Michel, 2012; Sekhar et al., 2016; Tracey, 2012; Way et al., 2015). However, flexibility regarding HRM practices may partially need some decentralized authority for the developed HRM practices to give room for each operating unit the ability to develop a suitable system of practice for its inimitable competitive situations (Ketkar \& Sett, 2010; Michel \& Michel, 2012; Sekhar et al., 2016; Tracey, 2012; Way et al., 2015; Wright et al., 1998). This is also because local autonomy and decentralization increase flexibility through promoting the processes of markets and competitors' evaluation, as well as evaluation of reconfiguration and transformation of capabilities before competition (Eisenhardt \& Martin, 2000; Teece et al.,1997; Teece, 2007).

HRM practices and coordination flexibilitycoordination flexibility as used in HRM practices deals with how swiftly the practices could be recreated, reconfigured, as well as redeployed. Most of the studies related to fit between strategy and HRM practices assume that the human resource department will swiftly, effectively and efficiently create and carry out new practices which are in line with the firm's strategic desires and environment without difficulties (Martin-Alcazar et al., 2005; Gerhart, 2007; Wright \& Sherman,1999).Though, studies have argued that, once administrative systems are in place, they are intractable (Gerhart \& Milkovich, 1990; Snell \& Dean, 1994). The reason for this is because numerous forces which include corporate regulations, written records, employee expectations, and organizational traditions will hold back these systems. Therefore, any flexibility of HRM practices model must take into consideration the theoretic field of structural inertia (Thompson, 2017) and need to explore the effect of institutionalization, political and bureaucratic processes on the HRM practices inertia (Wright \&McMahan, 1992).Significantly, one objective of evolving flexibility in HRM practices is to create accurate and timely feedback systems for the effectiveness of system of practices or a specific practice.

In conclusion, the ability HRM to be used efficiently on various situations can make can vary. The reason for this variability is the changeability in the practices permitted across locations, the quickness/ease of employing suitable practices, and the rapidity of obtaining feedback based on the usage of the selected practice(s)(Carvalho \& Cabral-Cardoso, 2008; Chang et al., 2013; Kaiser et al., 2015; Knox \& Walsh, 2005; Stankevičiūtė \& Savanevičienè, 2018; Wright, 1994; Zhang et al., 2015).Therefore, the overall flexibility of the organization will increase when some certain degree of HRM practices are flexible (on both resource and coordination flexibility).

\section{Flexibility and Employee Skills :}

Most studies on the types and ranges of employee skills based on the usage of HRM practices have focused on examining the roles of human resources in improving organization flexibility (Beltrán-Martín et al., 2008; Bhattacharya et al., 2005). HRM practices analysis, resource and coordination flexibility are pertinent to employee skills.

Employee skills and resource flexibility- this is defined as the number of possible substitutes uses in which employee skills can be used. The capability of each worker to work in various capacities is one of the features of employee skills and resource flexibility. An employee who possess a broad set of skills that allows him to achieve a huge number of various tasks and deliver operational resource flexibility on a daily basis (Feuille et al., 1995; Boxall \& Purcell, 2011;MacDuffie, 1995; Snell \& Dean, 1992).Therefore, skill-based pay plans offer a way of inspiring the growth of such comprehensive skill sets (Mitra et al., 2011; Ledford, 1995;Svetlik et al., 2007).

Moreover, management may use a longer-term fashion to carry out resource flexibility. In today's environment, the fast technological change and the new psychological contract which provides "employability" by developmental experiences has made the rapidity at which employees learn to carry out new tasks increasingly more imperative (Ehrlich, 1994; Guion,1997; Guion, 2011; MartínezSánchez et al., 2014). Therefore, instead of concentrating on the instant breadth of skills, there is a need for managers to also create flexibility through making sure that employees have the basic skills that would allow them to develop comprehensive skills in the nearest future.

Employee skills and coordination flexibility - this entails how employees that possess different skills could be swiftly redeployed in the value-chain. Due to this, a lot of skills can be used by choosing a huge number of employees having low skills range and then deploy and redeploy them to where their skills are required. In other words, firms functioning in other markets could move employee(s) having the skills from one market to the other.

Gradually, organizations are attaining coordination 
flexibility of skills through the use of contingent employees by hiring persons with a low set of skills to the specified projects.

Then, after completing the project or replacing the product, the organizations will release the casual workers and another set of casual workers whose low skill sets meet the requirements of the new projects, is used (Kochan et al., 1994).

\section{Flexibility and Employee Behavioral Repertoires :}

The flexibility of the firm is determined by the flexibility of employee behaviour. MacDuffie (1995, p.199) noted the significance of employee behaviour and its difference from employee skills by stating that "Skilled and knowledgeable workers who are not motivated are unlikely to contribute any discretionary effort. Motivated workers who lack skills or knowledge may contribute discretionary effort with little impact on performance". He stressed that the needed motivation to carryout discretionary effort comes from the employees' belief that there is link between their individual interests and the firm interests. Also,Boxall (1999) differentiated between evolving employees' skills (which is the "can do" goal of strategic HRM) and promoting commitment and motivation to align employee behaviour to firm's interest (which stands as the "will-do" goal of strategic HRM).

Organizational flexibility transpires when employees exhibit suitable behavioural scripts in any given circumstances. The behavioural scripts include the arrays of behavioural events anticipated by a person (Betsch \& Haberstroh, 2014; Vallacher \& Wegner, 2014)and can be compared to "routines" as known by other scholars (Heide, 2009; Hruby, 2001; Vera, 2016). Meanwhile, a script is kept as a serial unit of consideration which is referred to at suitable circumstances during human operation. People hold scripts for circumstances that have occurred to them, and the scripts give collective meanings and behaviours that enable coordinating activities in a social system (Fox et al., 2013; Sammeck, 2012; Sandaker, 2009; Simon \&March, 2006).

The flexibility of organizations is derived from the accessibility of massive repertoires of behavioural scripts among the workforces. It is essential to have flexibility so that there can be alteration of existing routines in reply to non-transient fluctuations in the environment (Weick, 1991a; Weick, 2006b; Weick, 2007c). The firms needs to have an adequate repertoire of original scripts among firm members that will allow them to identify and accept these changes.

Behavioural scripts and resource flexibilitybehavioural scripts are enormously pertinent to resource flexibility since a script appears stronger as more of it is applied (Kehr, 2004; Schank \& Abelson,2013). Therefore, as workers engross in tedious managing of circumstances by using a specific script, they increase the probability of selecting that script in representing a specific circumstance. Intrinsically, then, the institutionalization and bureaucratization of HRM practices may took place regarding behavioural scripts of individuals. The script will be institutionalized; therefore, it will lose its novelty and becomes parts of the firm's objective reality (Meyer, 2010).
HRM practices can either have a strong positive influence or a strong negative influence on behavioural resource flexibility of a firm. On the one hand, behavioural flexibility can only be decreased with some very particular behavioural appraisal systems which include rigid standard operating processes, narrow job descriptions, and behavioural observation scales (Gabris \& Ihrke, 2000a; Gabris \& Ihrke, 2001b; Landy et al., 2017; Rynes et al., 2002). On the other hand, developmental assignments or experiences are generally meant to increase the behavioural repertoires of managers. Managers face many challenges and proffer solutions to them when working in businesses and departments, which has increased their capability to identify a larger variation of contingencies and have a larger experience set of behavioural responses (Ford, 2014).

Behavioural scripts and coordination flexibilitydiversity of perspectives of a firm has been reduced since the homogeneity of behavioural scripts has increased, therefore decreasing the possibility for conflict. Since the same scripts relating to suitable responses to equally perceived circumstances are shared by members, the scripts also work as mechanisms for coordinating. However, the positive advantages of increasing coordination and reducing conflict might be offset by the negative influence of reduced diversity of perspectives. People with varied scripts bring diverse interpretations and enactment choices (Weick, 1991a; Weick, 2006b; Weick, 2007c). Varied perspectives generate coordination and conflict issues. This highlights the need for coordination flexibility that allows for synthesizing and deploying varied viewpoints in a manner that improves the decision effectiveness of firms.

In conclusion, an indicator of firms' flexibility is provided by the flexibility of employees' behaviour. Employees that have a lot of behavioural scripts, and are motivated to use them in suitable circumstances, instead of always following standard operating processes. This will improve the possibility of the organization recognizing new competitive circumstances and replying suitably.

In the same vein, firms achieve flexibility through coordinating behavioural scripts across groups and individuals.

\section{Methodology}

The majority of the past research on strategic HRM has been carried out in several different industries at the same time (Altarawneh \& Aldehayyat, 2011; Davision et al., 1996; Huselid, 1995; Ichniowski, 1990). However, examining strategic HRM in a single industry, with a limited population is supported by Cappelli and Neumark (2001).Particularly, it has been stressed that measuring variables is more probable and well defined if a study is concentrated on a specific sector; also, that "within an industry, studies automatically control for factors that differ among industries" (Ichniowski et al., 1995, p. 304).

The global increase of Internet usage and fast growth of landline and mobile usage in Jordan has led to an increase in demand for products and services. The Jordanian telecommunication industry is very vital to the Jordanian economy and is one of the most lucrative and innovative industries in Jordan (TRC, 2018). In addition, the Jordanian telecommunications industry is relatively developed, 
saturated and very competitive in the Jordanian market (TRC, 2018). As the telecommunications firms are challenged with intense competition, their profits are affected by high costs and charges, and the threat of new entrants to the market.

This has made it crucial for firms in the Jordanian telecommunications industry to be more innovative by developing new products and services for survival and achieve competitive advantage. Moreover, the telecommunications industry has played a significant role in improving the economy of Jordan. The telecommunication industry has contributed more than $10 \%$ to the GDP of Jordan, which made it a highly dynamic and imperative industry in Jordan (World Bank Jordan Economic Monitor, 2018).

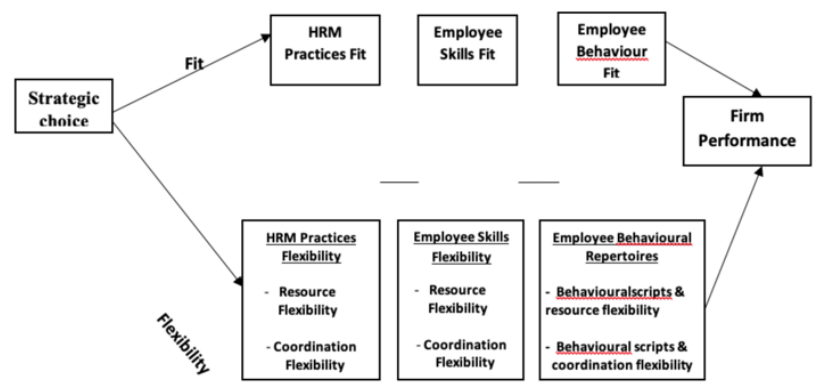

Fig. 1. Conceptualization of fit and flexibility in strategic HRM in Jordanian Telecommunication sector.

\section{CONCLUSION}

Strategic HRM has not given be enough significant attention in Jordan (Aladwan et al., 2014;Ameinfo, 2006; Bhanugopan et al., 2013;Menafn, 2008; Abu-Doleh \& Weir,2007). Past reports and subjective evidence through the Ministry of Industry and Trade imply that HRM departments in some Jordanian organizations appear to lack creativity and are ignoring their activities and duties (Aladwan et al., 2014; Ameinfo, 2006; Bhanugopan et al., 2013; Menafn, 2008; Weir \& Abu-Doleh, 2007). Due to this situation, these organizations are facing key issues relating to the growth of human capital, which includes: shortage of skilled employees and high turnover rates (AbuAlRub \& Nasrallah, 2017; Alhamwan et al., 2015; Alawneh et al., 2015). These problems have been fueled by low spending on training, planning, and research and development (Altarawneh, 2009; Al-Athari \& Zairi, 2002; Higazee et al., 2016; Menafn, 2008).

In addition, there is need for Jordanian firms particularly those in the telecommunication sector to improve their strategic HRM which will increase their productivity and organizational performance. This will be achieved by applying strategic HRM which fit in into their environment and apply flexibility into their strategic HRM settings when there is change in their business environment. This will improve their employees' skills and performance through HRM practices that is in control of the development and acquisition of the firm's human capital (Othman, 2009; Perez Lopez et al., 2005; Huselid\& Becker, 2011). When recruiting practices is done based on effective, efficient and reliable selection procedures, it will equip the organization with well qualified employees and have an important influence on the quality and type of knowledge and skills they possess (Guest, 1997; Richard \& Johnson, 2001; Salaman et al., 2005).

This study is a conceptual study, where it conceptualized a framework for examining fit and flexibility in strategic HRM in a single industry that is the Jordanian telecommunication sector. Both strategic fit and strategic flexibility are applicable in any industry but in today's world of increased uncertainty, flexibility has become a necessity for organizations in order to maintain and sustain their competitive advantages (Xiu et al., 2017). Thus, an emphasis should be placed on strategic flexibility in such a dynamic sector like the Jordanian telecommunication sector to improve their productivity, performance and achieve competitive advantage. Strategic flexibility will be achieved in the Jordanian telecommunication sector if it relies on developing innovative and sustainable HR practices to stay competitive in their rapidly changing and dynamic business environment.

\section{REFERENCES}

Abdalla, I., \& Al-Homoud, M. (1995). A survey of management training and development practices in the state of Kuwait. Journal of Management Development, 14(3), 14-25

AbuAlRub, R. F., \& Nasrallah, M. A. (2017). Leadership behaviours, organizational culture and intention to stay amongst Jordanian nurses. International Nursing Review.

Abdelhafiz, I. M., Alloubani, A. M. \&Almatari, M. (2016). Impact of leadership styles adopted by head nurses on job satisfaction: a comparative study between governmental and private hospitals in Jordan. Journal of Nursing Management, 24, 384-392.

Abu-Doleh, J. (2000). The Jordanian Financial and Manufacturing Human Resource Managers: A Profile. Al-Manarah, 6(2), 57-76

Abu-Doleh, J., \& Weir, D. (1997). Management Training and Development Needs Analysis Practices in the Jordanian Private Sector. Middle East Business Review, 2(1), 80-87

Abu-Doleh, J., \& Weir, D. (2007). Dimensions of performance appraisal systems in Jordanian private and public organizations. International Journal of Human Resource Management, 18(1), 75-84

Afana, G. (2004). Valuation of employees' job satisfaction in Jordanian banking sector and performance. Al-Manarah, 7(1), 13-30

Aladwan, K., Bhanugopan, R., \& Fish, A. (2014). Human resource management practices among frontline employees in the Jordanian organizations: Navigating through the crossroads of change and challenge. International Journal of Commerce and Management, 24(1), 6-24.

Al-Athari, A., \& Zairi, M. (2002). Training evaluation: An empirical study in Kuwait. Journal of European Industrial Training, 26(5), 241-251

Alawneh, S. M. A., Ahmad, A. A., \& Siron, R. (2015). The Mediating Effect of Employees' Job Satisfaction Between Leadership Styles and Patients Satisfaction in the Jordanian Public Hospitals. International Review of Management and Business Research Vol. 4 Issue. 3

Alhamwan, M., Mat, N., \& AlMuala, I. (2015). The Impact of Organizational Factors on Nurses Turnover Intention Behavior at Public Hospitals in Jordan: How Does Leadership, Career Advancement and Pay-Level Influence the Turnover Intention Behavior among Nurses. Journal of Management and Sustainability; Vol. 5, No. 2.

Al-Rasheed, A. (1994). Bank Managers in Jordan: A Study of Motivation, Job Satisfaction and Comparative Organisational Practices. Unpublished PhD Thesis, University of Kent.

Al-Shaikh, F. (1997). The Jordanian Entrepreneur: A Profile. Abhath AlYarmouk, 13(4), 9-17.

Akingbola, K. (2013). Contingency, fit and flexibility of HRM in nonprofit organizations. Employee Relations, 35(5), 479-494.

Altarawneh, I. (2009). Training and Development Evaluation in Jordanian Banking Organizations. Research and Practice in Human Resource Management, 17(1), 1-23.

Altarawneh, I. I., \&Aldehayyat, J. S. (2011). Strategic human resources management (SHRM) in Jordanian hotels. International Journal of Business and Management, 6(10), 242. 
Ameinfo (2006), "The Jordanian Association of Pharmaceutical Manufacturers announces the launch of the Centre of Excellence", available at: www.ameinfo.com/81496.html

Baird, L., \& Meshoulam, I. (1988). Managing two fits of strategic human resource management. Academy of Management review, 13(1), 116128.

Bantel, K., \& Jackson, S. 1989. Top management and innovations in banking: Does the composition of the top team make a difference? Strategic Management Journal 10: 107-124.

Beltrán-Martín, I., Roca-Puig, V., Escrig-Tena, A., \& Bou-Llusar, J. C. (2008). Human resource flexibility as a mediating variable between high performance work systems and performance. Journal of Management, 34(5), 1009-1044.

Betsch, T., \& Haberstroh, S. (Eds.). (2014). The routines of decision making. Psychology Press.

Bhattacharya, M., Gibson, D. E., \& Doty, D. H. (2005). The effects of flexibility in employee skills, employee behaviors, and human resource practices on firm performance. Journal of Management, 31(4), 622-640.

Bhanugopan, R., Aladwan, K., \& Fish, A. (2013). A structural equation model for measuring human resource management practices in the Jordanian organisations. International Journal of Organizational Analysis, 21(4), 565-587.

Boxall, P. F. (1999). Human resource strategy and industry-based competition: A conceptual framework and agenda for theoretical development. Research in Personnel and Human Resource Management, Supplement, 4, 259-281.

Boxall, P., \& Purcell, J. (2011). Strategy and human resource management. Macmillan International Higher Education.

Budhwar, P., and Mellahi, K. (2006), Managing Human Resources in the Middle East, Routledge, New York.

Cappelli, P., and Neumark, D. (2001). Do high performance work practices improve? establishment level outcomes?.Industrial and Labor Relations Review, 54 (4), 737-775.

Carvalho, A., \& Cabral-Cardoso, C. (2008). Flexibility through HRM in management consulting firms. Personnel Review.

Chang, S., Gong, Y., Way, S. A., \& Jia, L. (2013). Flexibility-oriented HRM systems, absorptive capacity, and market responsiveness and firm innovativeness. Journal of Management, 39(7), 1924-1951.

Davision, III., Worrell, L., and Fox, B. (1996). Early retirement programs and firm performance. Academy of Management Journal, 39 (4), 970-984. http://dx.doi.org/10.2307/256719

Delery, J. E., \& Doty, D. H. 1996. Theoretical frameworks in strategic human resource management: Universalistic, contingency, and configurational perspectives. Academy of Management Journal, 39: 802-835.

Delery, J. E., \& Roumpi, D. (2017). Strategic human resource management, human capital and competitive advantage: is the field going in circles?. Human Resource Management Journal, 27(1), 1-21.

Ehrlich, C. 1994. Creating an employer-employee relationship for the future. Human Resource Management, 33: 491-502.

Eisenhardt, K. M., \& Martin, J. A. (2000). Dynamic capabilities: what are they?. Strategic management journal, 21(10-11), 1105-1121.

Feuille, P., Dwyer, D. S., \& Hamermesh, D. S. (1995). Human Resource Bundles and Manufacturing Performance: Organizational Logic and Flexible Production Systems in the World Auto Industry. Industrial and Labor Relations Review, 48(2).

Ford, J. K. (2014). Employee Development: Construct Validation Issues. In Improving Training Effectiveness in Work Organizations (pp. 165202). Psychology Press.

Fox, J., Cooper, R. P., \& Glasspool, D. W. (2013). A canonical theory of dynamic decision-making. Frontiers in psychology, 4, 150.

Gabris, G. T., \& Ihrke, D. M. (2000). Improving employee acceptance toward performance appraisal and merit pay systems: The role of leadership credibility. Review of Public Personnel Administration, 20(1), 41-53.

Gabris, G. T., \& Ihrke, D. M. (2001). Does performance appraisal contribute to heightened levels of employee burnout? The results of one study. Public Personnel Management, 30(2), 157-172.

Gerhart, B. (2007). Horizontal and vertical fit in human resource systems. Perspectives on organizational fit, 1, 317-348.

Gerhart, B., \& Milkovich, G. T. (1990). Organizational differences in managerial compensation and financial performance. Academy of Management journal, 33(4), 663-691.

Gerstein, M., \& Reisman, H. (1983). Strategic selection: Matching executives to business conditions. Sloan Management Review, 24(2): 33-49

Guest, D. E. (1997). Human resource management and performance: a review and research agenda. International journal of human resource management, 8(3), 263-276.
Guion, R. (1997). Criterion measures and the criterion dilemma. In N. Anderson \& P. Herriot (Eds.), International handbook of selection and assessment: 267-286. New York: Wiley.

Guion, R. M. (2011). Assessment, measurement, and prediction for personnel decisions. Routledge.

Gupta, A. (1984). Contingency linkages between strategy and general managers' characteristics: A conceptual examination. Academy of Management Review, 9: 399-412.

Gupta, A. K., \& Govindarajan, V. 1984. Business unit strategy, managerial characteristics, and business unit effectiveness at strategy implementation. Academy of Management Journal, 27: 25-4 1.

Hambrick, D., \& Mason, P. 1984. Upper echelons: The organization as a reflection of its top managers. Academy of Management Review, 9: 193-206.

Heide, M. (2009). On Berger: A social constructionist perspective on public relations and crisis communication. In Public relations and social theory (pp. 51-69). Routledge.

Higazee, M. Z. A., Rayan, A., \& Khahl, M. (2016). Relationship between Job Stressors and Organizational Support among Jordanian Nurses. American Journal of Nursing Research, Vol. 4, No. 3, 51-55

Hitt, M., \& Tyler, B. (1992). Strategic decision models: Integrating different perspectives. Strategic Management Journal, 12: 327-351.

Hruby, G. G. (2001). Sociological, postmodern, and new realism perspectives in social constructionism: Implications for literacy research. Reading Research Quarterly, 36(1), 48-62.

Huselid, M. A. (1995). The impact of human resource management practices on turnover, productivity, and corporate financial performance. Academy of management journal, 38(3), 635-672.

Huselid, M. A., \& Becker, B. E. (2011). Bridging micro and macro domains: Workforce differentiation and strategic human resource management.

Ichniowski, C. (1990). Human resource management systems and the performance of US manufacturing businesses (No. w3449). National Bureau of Economic Research.

Ichniowski, C., Shaw, K., \& Prennushi, G. (1995). The effects of human resource management practices on productivity (No. w5333). National bureau of economic research.

Ichniowski, C., Shaw, K., \& Prennushi, G. (1997). The effects of human resource management on productivity: a study of steel finishing line. American Economic Review, 87 (3), 291-313.

Jackson, S. E., Schuler, R. S., \& Rivero, J. C. (1989). Organizational characteristics as predictors of personnel practices. Personnel Psychology, 42: 727-786.

Kaiser, S., Kozica, A., Swart, J., \& Werr, A. (2015). Human Resource Management in Professional Service Firms: Learning from a framework for research and practice. German Journal of Human Resource Management, 29(2), 77-101.

Kehr, H. M. (2004). Integrating implicit motives, explicit motives, and perceived abilities: The compensatory model of work motivation and volition. Academy of management review, 29(3), 479-499.

Kerr, J. (1982). Assigning managers on the basis of the life cycle. Journal of Business Strategy, 2(4): 58-65

Ketkar, S., \& Sett, P. K. (2010). Environmental dynamism, human resource flexibility, and firm performance: analysis of a multi-level causal model. The International Journal of Human Resource Management, 21(8), 1173-1206.

Knox, A., \& Walsh, J. (2005). Organisational flexibility and HRM in the hotel industry: evidence from Australia. Human Resource Management Journal, 15(1), 57-75.

Kochan, T., Smith, M., Wells, J., \& Rebitzer, J. 1994. Human resource strategies and contingent workers: The case of safety and health in the petrochemical industry. Human Resource Management, 33: 5577.

Landy, F., Zedeck, S., \& Cleveland, J. (2017). Performance measurement and theory. Routledge.

Ledford Jr, G. E. (1995). Paying for the skills, knowledge, and competencies of knowledge workers. Compensation \& Benefits Review, 27(4), 55-62.

Lengnick-Hall, C. A., \& Lengnick-Hall, M. L. 1988. Strategic human resources management: A review of the literature and a proposed typology. Academy of Management Review, 13: 454-470.

Perez Lopez, S., Montes Peon, J. M., \& Vazquez Ordas, C. J. (2005). Human resource practices, organizational learning and business performance. Human Resource Development International, 8(2), $147-164$.

MacDuffie, J. 1995. Human resource bundles and manufacturing performance: Organizational and flexible production systems in the world auto industry. Industrial and Labor Relations Review, 48: 197221. 
Martin-Alcazar, F., Romero-Fernandez, P. M., \& Sánchez-Gardey, G. (2005). Strategic human resource management: integrating the universalistic, contingent, configurational and contextual perspectives. The International Journal of Human Resource Management, 16(5), 633-659.

Martínez-Sánchez, A., Vela-Jiménez, M. J., Pérez-Pérez, M., \&AbellaGarcés, S. (2014). Innovation, Organizational Flexibility, and Performance. In Innovative Management and Firm Performance (pp. 235-253). Palgrave Macmillan, London.

Melham, Z. (2004). Significant conditions of employees' recruitment: the case of Jordanian four star hotels. Unpublished thesis, The University of Jordan.

Menafn (2008), “Jordan's pharmaceuticals industry suffers lack of skilled labour", available www.menafn.com/qn_news_story_s.asp?storyid $1 / 41093185267$ (accessed 10 July 2009)

Meyer, J. W. (2010). World society, institutional theories, and the actor. Annual review of sociology, 36, 1-20.

Michel, J., \& Hambrick, D. (1992). Diversification posture and top management team characteristics. Academy of Management Journal, 35: 9-37.

Michel, R. D. J., \& Michel, C. E. J. (2012). Faculty satisfaction and workfamily enrichment: The moderating effect of human resource flexibility. Procedia-Social and Behavioral Sciences, 46, 5168-5172.

Miles, R. E., \& Snow, C. C. 1984. Designing strategic human resources systems. Organizational Dynamics, 13: 36-52.

Milliman, J., Von Glinow, M. A., \& Nathan, M. 1991. Organizational life cycles and strategic international human resource management in multinational companies: Implications for congruence theory. Academy of Management Review, 16: 318-339.

Mitra, A., Gupta, N., \& Shaw, J. D. (2011). A comparative examination of traditional and skill-based pay plans. Journal of Managerial Psychology, 26(4), 278-296.

Montemayor, E. 1996. Congruence between pay policy and competitive strategy in high-performing firms. Journal of Management, 22: 889 908.

Nadler, D., \& Tushman, M. (1980). A diagnostic model for organizational behaviour. In $\mathrm{J}$

R. Hackman, E. E. Lawler, \& L. W. Porter (Eds.), Perspectives on behaviour in organizations: 83-100. New York: McGraw-Hill.

Olian, J. D., \& Rynes, S. L. 1984. Organizational staffing: Integrating practice with strategy. Industrial Relations, 23: 170-183.

Othman, A. E. A. (2009). Strategic HRM practices: Perspectives of Malaysian and Japanese owned companies in Malaysia. Global Business \& Management Research, 1(1)

Paauwe, J. (2004). HRM and performance: Achieving long-term viability. Oxford University Press on Demand.

Richard, O. C., \& Johnson, N. B. (2001). Strategic human resource management effectiveness and firm performance. International Journal of Human Resource Management, 12(2), 299-310.

Rynes, S. L., Brown, K. G., \& Colbert, A. E. (2002). Seven common misconceptions about human resource practices: Research findings versus practitioner beliefs. Academy of Management Perspectives, 16(3), 92-103.

Salaman, G., Storey, J., \& Billsberry, J. (Eds.). (2005). Strategic human resource management: Theory and practice. Sage.

Sammeck, J. (2012). A new institutional economics perspective on industry self-regulation. Gabler Verlag/Springer Fachmedien Wiesbaden.

Sanchez, R. 1995. Strategic flexibility in product competition. Strategic Management Journal, 16: 135-159.

Sandaker, I. (2009). A selectionist perspective on systemic and behavioral change in organizations. Journal of Organizational Behavior Management, 29(3-4), 276-293.

Schuler, R. S., \& Jackson, S. 1987. Linking competitive strategies with human resource management practices. Academy of Management Executive, 1: 207-219.

Sekhar, C., Patwardhan, M., \& Vyas, V. (2016). A study of HR flexibility and firm performance: a perspective from IT industry. Global Journal of Flexible Systems Management, 17(1), 57-75.

Schank, R. C., \& Abelson, R. P. (2013). Scripts, plans, goals, and understanding: An inquiry into human knowledge structures. Psychology Press

Simon, H., \& March, J. (2006). Administrative behavior and organizations Organizational Behavior 2: Essential theories of process and structure, 2(41)

Snell, S. A. 1992. Control theory in strategic human resource management: The mediating effect of administrative information. Academy of Management Journal, 35: 292-327
Snell, S. A., \& Dean Jr, J. W. (1994). Strategic compensation for integrated manufacturing: The moderating effects of jobs and organizational inertia. Academy of Management Journal, 37(5), 1109-1140.

Snow, C. C., \& Snell, S. A. (1993). Staffing as strategy. Personnel selection in organizations, 448,478 .

Stankevičiūtè, Ž., \& Savanevičienè, A. (2018). Designing sustainable HRM: The core characteristics of emerging field. Sustainability, $10(12), 4798$

Svetlik, I., Stavrou-Costea, E., Vakola, M., Soderquist, K. E., \& Prastacos, G. P. (2007). Competency management in support of organisational change. International journal of manpower.

Teece, D., Pisano, G., \& Shuen, A. 1997. Dynamic capabilities and strategic management. Strategic Management Journal, 18: 509-533.

Teece, D. J. (2007). Explicating dynamic capabilities: the nature and microfoundations of (sustainable) enterprise performance. Strategic management journal, 28(13), 1319-1350.

Thompson, J. D. (2017). Organizations in action: Social science bases of administrative theory. Routledge.

Torrington, K., Wright, T., \& Tyson, A. (2005). Toward a unifying framework for exploring fit and flexibility in strategic human resource management. Academy of Management Review, 21(1), 5669.

Tracey, J. B. (2012). A contextual, flexibility-based model of the HR-firm performance relationship. Management decision, 50(5), 909924.TRC 2018, "Telecommunications Regulatory Commission Jordan",

available: $<$ http://www.trc.gov.jo/images/stories/pdf/TRC\%20Annual $\% 20$ Report\%20English(high).pdf?lang=english $>$.

Vallacher, R. R., \& Wegner, D. M. (2014). A theory of action identification. Psychology Press.

Venkatraman, N. (1989). The concept of fit in strategy research: Toward a verbal and statistical correspondence. Academy of Management Review, 14: 423-444.

Vera, H. (2016). Rebuilding a classic: The social construction of reality at 50. Cultural Sociology, 10(1), 3-20.

Way, S. A., Tracey, J. B., Fay, C. H., Wright, P. M., Snell, S. A., Chang, S \& Gong, Y. (2015). Validation of a multidimensional HR flexibility measure. Journal of Management, 41(4), 1098-1131.

Wei, L. Q. (2006). Strategic human resource management: Determinants of fit. Research and Practice in Human Resource Management, 14(2)

Weick, K. 1979. The social psychology of organizing. Boston: AddisonWesley.

Weick, K. E. (1991). The nontraditional quality of organizational learning. Organization science, 2(1), 116-124.

Weick, K. E. (2006). Faith, evidence, and action: Better guesses in an unknowable world. Organization studies, 27(11), 1723-1736.

Weick, K. E. (2007). Drop your tools: On reconfiguring management education. Journal of Management Education, 31(1), 5-16.

Wiersma, M., \& Bantel, K. 1992. Top management team demography and corporate strategic change. Academy of Management Journal, 35 91-121. World Bank Jordan Economic Monitor 2013, available: $<$ http://www.worldbank.org/content/dam/Worldbank/docu ment/MNA/Jordan EM Spring 2018.pdf $>$

Wright, P. M., McMahan, G. C., \& McWilliams, A. 1994. Human resources and sustained competitive advantage: A resource-based perspective. International Journal of Human Resource Management, 5: $301-326$

Wright, P. M. (1998). Strategy-HR fit: does it really matter?Human Resource Planning, 21(4), 56-58.

Wright, P. M., \& McMahan, G. C. (1992). Theoretical perspectives for strategic human resource management. Journal of management, $18(2), 295-320$

Wright, P. M., \& McMahan, G. C. (2011). Exploring human capital: putting 'human'back into strategic human resource management Human resource management journal, 21(2), 93-104.

Wright, P. M., \& Sherman, W. S. (1999). Failing to find fit in strategic human resource management: Theoretical and empirical problems. Research in personnel and human resources management, 4, 53-74.

Wright, P. M., Smart, D. L., \& McMahan, G. C. (1995). Matches between human resources and strategy among NCAA basketball teams. Academy of Management journal, 38(4), 1052-1074.

Wright, P. M., \& Snell, S. A. (1998). Toward a unifying framework for exploring fit and flexibility in strategic human resource management. Academy of management review, 23(4), 756-772.

Wright, P. M., \& Snell, S. A. (1991). Toward an integrative view of strategic human resource management. Human resource management review, 1(3), 203-225.

Xiu, L., Liang, X., Chen, Z., \& Xu, W. (2017). Strategic flexibility, innovative HR practices, and firm performance: A moderated mediation model. Personnel Review, 46(7), 1335-1357. 
Youndt, M., Snell, S. A., Dean, J. W., Jr., \&Lepak, D. P. (1996). Human resource management, manufacturing strategy, and firm performance. Academy of Management Journal 39: 836-866

Zhang, M. M., Bartram, T., McNeil, N., \& Dowling, P. J. (2015). Towards a research agenda on the sustainable and socially responsible management of agency workers through a flexicurity model of HRM. Journal of Business Ethics, 127(3), 513-523. 